
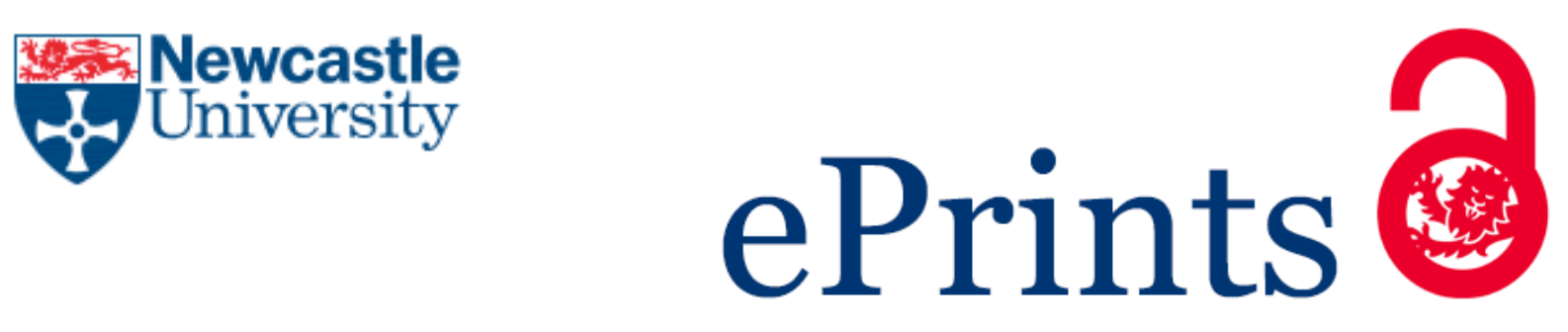

Moonie S.

Figuration, Literalism, Realism

Oxford Art Journal 2016, 39(1), 131-138.

\title{
Copyright:
}

This is a pre-copyedited, author-produced PDF of an article accepted for publication in Oxford Journal of Art following peer review. The version of record Moonie S. 'Figuration, Literalism, Realism,'. Oxford Art Journal 2016, 39(1), 131-138 is available online at:

http://dx.doi.org/10.1093/oxartj/kcv031

DOI link to article:

http://dx.doi.org/10.1093/oxarti/kcv031

Date deposited:

$06 / 05 / 2016$

Embargo release date:

03 March 2018

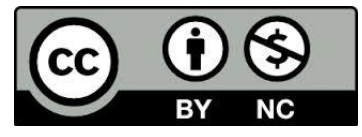

This work is licensed under a Creative Commons Attribution-NonCommercial 3.0 Unported License 


\section{Figuration, Literalism, Realism}

\section{Stephen Moonie}

Robert Slifkin, Out of Time: Philip Guston and the Refiguration of Postwar American Art (Berkeley: University of California Press), 24 col, 79 b\&w illus, 246 pp, \$60, Hardcover ISBN: 9780520275294.

Alex Potts, Experiments in Modern Realism: World Making in Postwar European and American Art (New Haven and London: Yale University Press, 2013), 128 col, 73 b\&w illus, 472 pp, \$65, Hardcover ISBN: 9780300187687,.

The relationship between art and the real has a long and complex history: indeed this relationship might be said to form the crux around which art history defines itself as a discipline. For scholars of postwar modernism, the problem takes on a particular salience. According to the conventional modernist narrative, the agonistic struggle between abstract and representational modes gave birth to the 'triumph' of Abstract Expressionism. For Clement Greenberg, this liberation was aesthetic: for Harold Rosenberg, it was of an existential nature (if only potentially). In retrospect, it has become clear that this development was subtended by the social and political climate of the Cold War (although quite how that is brought to bear upon the art is still a matter of debate). In the 1960 s, the splintering of modernism into a variety of putatively postmodern practices threatened to supersede the abstract and the representational as viable practices. These recent studies by Robert Slifkin and Alex Potts open up this terrain for reassessment: both suggest that the relationship between art and the world is neither secure nor straightforward. 
Slifkin's concentrates on Philip Guston: in particular, his now legendary Marlborough show in 1970. Guston's show was hailed as a 'return to figuration' after his phase as an Abstract Expressionist (although as we shall see, Slifkin challenges this notion). But Guston's singularly odd depictions: most notably his Ku Klux Klan figures plotting, smoking, riding around town, even painting self-portraits-were greeted with outrage and consternation. This was not manufactured outrage, but a genuine shock to Guston's contemporaries, some of whom were too embarrassed even to speak to him at the opening: the show also brought an end to his close friendship with the musician Morton Feldman. Guston is a singular figure, then, not only because of the unprecedented style of his late work, but from an art-historical perspective. Guston does not fit into the modernist narrative of purity (neither the purity of Greenberg, nor the modernist apostasy of Donald Judd or Joseph Kosuth), nor does he seem to fit into the wider shift of the 1960s towards an incipient postmodernism: it is difficult to imagine Guston getting along with Daniel Buren, Dan Graham, or Robert Smithson. It is here that Slifkin's study makes its contribution, in attempting to account for the singularity of Guston's late work, while simultaneously placing it within the wider context of the 1960s.

Slifkin claims that, for all its intractable oddness, Guston's late work nonetheless forms part of a set of shared cultural and historical concerns in the 1960s and 1970s. Central to Slifkin's argument is the claim that Guston's late work was not a 'return to figuration,' as it is often claimed. It was, Slifkin argues, 'a return to representational imagery' (p. 5). This distinction-between the representational and the figurative-might seem to be a relatively minor issue of terminology, but Slifkin takes his notion of 'figuration' from Paul de Man, where figuration is not the representation of recognisable human figures in painting, but rather a substitutive chain of 
metonymic signification put into play by painting (or the text, in de Man's case).

Taking his cue from the forbidding theory of de Man gives the reader an indication of Slifkin's approach, which has a pronounced literary bent: the first chapter is largely an exposition of theory. Nonetheless, although the reader may be impatient to get to Guston's painting, this preliminary discussion is necessary to set up Slifkin's broader argument.

The Marlborough show is often regarded as a 'return' because the Ku Klux Klan hoods had previously appeared in Guston's work in the 1930s, while the depiction of recognisable imagery recalled his work before the shift to abstraction in the 1940s. However, Slifkin argues that these later works are historically specific to the late 1960s, which Slifkin refers to as the 'figured world,' a term derived from the sociologist Daniel J. Boorstin. Boorstin's The Image: Pseudo-Events in America (1962) discussed the blurring of the fictive and the real, brought about initially by advertising and public relations, but later prevalent in politics and public life. ${ }^{1}$ Slifkin relates this loss of a stable relationship to the real to the theories of Marshall McLuhan, the rise of the mass media and the discourse of cybernetics. One might also point to examples such as the U.S. public's scepticism of the Warren Commission's report on the Kennedy assassination, as an instance of the disillusionment when historical events themselves appear fictional.

In this 'figured world,' Guston's motifs, while part of the context of the 1960s, do not speak directly of contemporary social or political realities. For Slifkin, reference to the real has become problematic; so, too has the notion of selfexpression. Guston is 'a ghost inhabiting the artworld' (p. 50), a memorable phrase Slifkin borrows from Harold Rosenberg's 'The American Action Painters' (1952). The term seems particularly apposite when one considers the Ku Klux Klan hoods in 
Guston's late works, especially The Studio (1969) where Guston imagines himself as a hooded Klansman pondering his next brushstroke.

The notion of 'figuration' is not only a designation of a fractured or unstable relationship to the world. It is also, according to Slifkin, a means to bridge the gap between the 'autonomous' art of the modern period with pre-modern art (p. 10). Figuration cuts across the abstract and representational divide of the 1950s, for abstract art can also be said to signify, even if it does not represent the world. Through this conceptual realignment, Slifkin brings Guston's work into line with his contemporaries.

In the second chapter, entitled 'Literal, Lateral, Historical,' Slifkin outlines a number of ways with which to understand what he terms Guston's 'counter-literalism' (p. 42). This notion might seem to run against the claim for 'figuration,' but only if one accepts at face value the distinction between an autonomous work of art with its representational counterpart. For Slifkin, then, Guston's figuration does not preclude literalism, of which he defines several kinds. The first is what he calls 'liberal literalness, a naïve faith in one's own ability to effect change and express oneself by the sheer force of one's earnestness...' (p. 33). Guston's work was regarded as 'too much' by the critic John Perrault: a clumsy attempt to grapple with the crises of the time. In Slifkin's words, they are liberal 'in their expression of guilt or impotence in the face of political corruption and civil unrest...' (p. 34). According to Slifkin, a similarly earnest, liberal literalness can be found in Norman Mailer's journalism: Armies of the Night (1968) and Miami and the Siege of Chicago (1969). This literalness went hand-in-hand with Mailer's combustible public persona: at a glamorous party in 1977, he reputedly accosted his literary rival Gore Vidal, punching him in the mouth. Wiping away the blood, Vidal paused, then responded with rapier- 
sharp coolness, 'Once again, Norman, words have failed you.'2 Guston's Marlborough paintings were regarded by his critics as equally impotent bluster.

This notion of literalism runs against the prevailing notion of a cool, impersonal literalism as seen in Kynaston McShyne's major group exhibition Information, at the Museum of Modern Art in 1970, or indeed in the contemporary minimalist work of Carl Andre, Donald Judd or Frank Stella. Guston’s ‘counterliteralism' operates according to what Slifkin terms 'lateralism,' setting up a sequential matrix of association between his paintings: so the light-bulbs, knobbly knees, hob-nailed boots, and Mickey-Mouse-style hands refer to each other across different paintings, each iteration setting up a different chain of meaning.Rosalind Krauss' 1971 account of Stella's use of series made a similar claim, which seems to lend support to Slifkin's argument that the notion of 'figuration' cuts across abstract and representational modes (although such a specific comparison might require more thorough investigation. ${ }^{3}$

Slifkin argues, however, that literalism had a historical element, making explicit reference to the iconography of his paintings from the 1930s. Guston grew up in Los Angeles where the Klan had a significance presence: they were involved in breaking strikes and they even vandalised an exhibition of Guston's paintings. ${ }^{4}$ However, Guston was not alone in the 1960s in his evocation of the 1930s. Roy Lichtenstein's brass Modern Sculpture (1967) evoked Art Deco, as did Robert Smithson in his essay 'Ultramoderne' (1967); Claes Oldenburg's Airflow Box (1965), which appeared on the cover of Art News in 1966, depicted the legendary Chrysler Airflow saloon, which was technologically-advanced but commercially doomed. For Slifkin, these examples testified to a fascination during the 1960s with the 1930s as a period of 'referential plenitude' (p. 91), a phenomenon also found in movies such as 
Bonnie and Clyde (1967), and in exhibitions such as The Thirties: Painting and Sculpture in America, held at the Whitney in 1967.

In Chapter 3, entitled 'Action Painting Refigured,' Slifkin makes an extensive case for Guston's relationship with the New York School of painting, especially his antagonistic relationship with Jackson Pollock. The two attended high school together in Los Angeles, but their adult relationship was anything but smooth, as Slifkin drily recounts the following outbursts:

Pollock trying to throw Guston down a flight of stairs... Pollock publicly ridiculing Guston... during a party in spring 1945, shouting at him drunkenly, "I won't stand for the way you're painting!" and, at least according to Guston, threatening to throw him out a window; Pollock bursting into the Egan Gallery and tearing the paintings off the walls while "incoherently" blurting out derogatory remarks... and, during a party after the opening reception of Guston's 1955 show at Sidney Janis... attempting once again to throw Guston out a window (p. 135).

This one-sided litany of violence suggests a relationship similar to Krazy Kat, the George Herriman cartoon much admired by Guston. Krazy loves Ignatz the mouse, despite having bricks hurled at his head: likewise, Pollock's outbursts did not seem to diminish Guston's admiration for his work. In fact, Slifkin makes the case for the Marlborough show as Guston's 'long goodbye' to the New York School: a last shot at action painting in an era where action painting was no longer possible.

Rosenberg's notion of 'action' formed part of a dialogue which he shared with Guston over the years of their friendship. Slifkin's understanding of Rosenberg's notion of 'action' is not predicated upon notions of authenticity, however. Rather, the notion can be understood as being based upon 'artifice and performance, rather than 
physical gesticulation and psychological disclosure' (p. 145). ${ }^{5}$ Willem de Kooning told Guston that his Marlborough works were about 'freedom': or as Rosenberg put it, 'liberation from detachment' (p.142). But as Slifkin argues, Guston's was a pyrrhic victory, for the kind of authentic gesture presupposed by 'action' was no longer possible in the 'figured world' of the 1960s. It is rather, 'unfreedom': something Guston would not perhaps have disapproved. ${ }^{6}$

Guston's friendship with Rosenberg and de Kooning reveals his alignment against Greenberg and his group of favoured artists such as Stella and Kenneth Noland. Slifkin sees Flatlands (1970), with its ambiguous space inhabited by an assortment of Guston's characteristic motifs, as an ironic take on the 'flatness' of modernist painting, in tune with the Marlborough paintings more broadly (p.116). Further, the artist's friendship with Rosenberg brings into relief the literary aspects of Guston's work. Slifkin notes that the lightbulb motif in Guston's paintings-a motif often regarded as a biographical signifier of his childhood- has a pointed bottom, suggesting a speech bubble (p. 61). This makes explicit the desire to signify, to contaminate the painting's 'purity' with ideas. Further, Guston himself noted that when his painting was going well, it felt like the act of writing (p. 61). Guston also made a series of paintings of books, which Slifkin pays particular attention to: those books, which take the form of slabs, tablets, or even apartment blocks, emphasise both language and the metonymic functioning foregrounded by Slifkin.

The final chapter discusses the impossibility of self-expression in conjunction with other notions of 'badness' in the 1970s. Here Slifkin takes a turn towards pop culture, adducing examples such as Bob Dylan's notorious Self-Portrait (1970): an album so shoddy that it has long puzzled Dylan's obsessive fans. The record's cover, painted by Dylan himself, is equally slapdash. Slifkin leans towards the argument that 
Dylan was purposefully deconstructing his own myth, although the more commonplace view-that it was simply a lousy record-seems more convincing. Miles Davis' output from the early 1970s was equally bewildering: not just the lengthy passages of psychedelic mood music on Big Fun (1971), or the percussive monotony of On The Corner (1972): but more disquieting still was the bereaved, dissociated atmosphere on pieces like 'He Loved Him Madly' from 1973's Get Up With It. Slifkin argues that Guston's appropriation of 'badness,' along with Dylan's SelfPortrait and Davis' electric era, are indicative of the problematic of self-expression in a mediatised world. Despite the risks of this diversion, Slifkin's foray into pop-culture is satisfying and provocative, and the chapter nicely turns back towards the initial impetus behind the study: Slifkin's own puzzlement at seeing Guston's late paintings for the first time.

One might add the caveat, however, that Guston's late period did not renege upon former glories, as Davis and Dylan were charged with doing. In fact, it has come to define his career: he might otherwise have been remembered as a minor Abstract Expressionist. As Slifkin's rich account demonstrates, Guston's are certainly not bad paintings, however much they appropriate 'badness' as an idiom. Slifkin's closing chapter prompts the question: what differentiates 'badness' from the merely bad? The question is one for aesthetics, however. Another issue which lingers is how Guston's art relates to the real. Despite the problematic of the 'figured world,' Guston regarded himself as a realist. Is there a way of rethinking art's relationship to the world, in spite of the problematic of realism in the post-war period?

Alex Potts' study tackles this problem, and provides a counterpoint to the previous study. Whereas Slifkin focuses on a single artist, Potts approaches many of the major figures of the postwar period. Potts too, is interested in the issue of 
reference, but unlike Slifkin's rarified understanding of figuration, Potts makes the case for a critical realism engaged with the concrete stuff of the external world. $\mathrm{He}$ does not argue for an unproblematic understanding of reference: instead, he argues that for an art of realism to compel conviction, it must exist in a dialectical relationship to the world. In particular, the most compelling art of the post-war period must straddle the divide between art and non-art, each half of the dialectic mutually reinforcing the other. Potts calls this a 'radical realist impulse' (p. 10). In this sense, Potts reveals his modernist sympathies, for it is this very dialectic which pre-occupied critics such as Michael Fried, Clement Greenberg, Harold Rosenberg and Leo Steinberg.

While much of Potts' material will be familiar to readers familiar with the post-war canon of American and European art, his argument is distinguished by the claim that realism is a major tendency during the postwar period. This argument contrasts with the conventional modernist view that the representational gives way to the historical triumph of abstract painting. It also contrasts with the postmodern view espoused by Slifkin, that the real is mediated or inaccessible. Potts claims that realism is not merely the picturing or representation of recognisable content, instead arguing that 'the abandoning of traditional realist figuration is not to be equated... with an abandonment of representation' (p. 31). Potts' view might be aligned with Leo Steinberg's argument in his 1953 essay 'The Eye is a Part of the Mind,' that abstract art is not non-representational, but rather, it has the capacity to signify. Steinberg's is a stronger version of the claim by Greenberg that the representational as such was not objectionable (i.e. modernist objections to representation were not aesthetic but rather historically determined); or Fried's claim that the opposition 
between abstract and representational was 'uninteresting. ${ }^{7}$ However both critics' exclusive championing of abstract art renders the point moot.

In his opening section, 'The Case for Realism,' Potts sets out a distinction between Plato and Aristotle's theories of mimesis: the former's is 'world-reflecting,' looking outwards, whereas the latter's is 'world creating,' setting out an internally coherent, credible picture of reality (p. 45). Potts does not see the two modes as mutually contradictory, but rather as mutually compatible. This play between the interior and the exterior underpins Potts' understanding of realism as forming part of a dialectical engagement with the world, which he regards as a necessity for a critical art practice. This capacious definition allows Potts to include non-representational work such as Jackson Pollock and Cy Twombly, in addition to the performances of Joseph Beuys and Allan Kaprow. Further, the dialectical notion of art and non-art, self and world, allows Potts to circumvent the charge that realism is merely a mirroring of the world. Potts' understanding of realism might be compared with Charles Harrison's notion of the term: not as a style but as an ethical commitment to resist 'the pervasive simplifications of our political and economic culture. ${ }^{8}$ This notion seems corroborated by Potts' lucid overview of the debates between Lukács and Brecht over literary realism, and of Adorno and Sartre's thoughts on 'commitment.' Potts is sympathetic to Lukács' view that art needs a synthesising world-view which transcends the fragmentary or the immediate registers of experience. But Potts also acknowledges Brecht's claim that the capacious worldview of the $19^{\text {th }}$ century novel cannot suffice in the $20^{\text {th }}$ century.

Whereas Slifkin's argument is synchronic, Potts takes a more conventional approach, which is largely chronological. This makes it easier for the reader to follow his argument, but this straightforward armature belies the richness of Potts' 
discussion. His study is structured around four sections, each split into two chapters: these in turn deal with representative artists who are selected by and large for their critical and historical importance. Unfortunately, with the exception of Niki de Saint Phalle, women artists are entirely absent. Of course, omissions will always be a factor in any history where individual artists are chosen as emblematic of a wider tendency: but this is still a disappointing oversight. Potts acknowledges this and apologises on page 19. In doing so, he lists a number of women artists who could have plausibly figured in his account, such as Lee Krasner, Louise Nevelson and Carolee Schneeman. However, the acknowledgement only serves to lend ammunition to those likely to be critical of his omissions.

The first section, entitled 'Painting and the Substance of Things' pursues the notion of an interior-exterior dialectic as a condition of realism. However, Potts pursues this in the non-representational painting of Jackson Pollock. Following Rosalind Krauss and Anton Ehrenzweig, Potts claims that Pollock's paintings do not renounce the real: instead, they are structured around a polarity of figuration and nonfiguration, which Pollock wrestled with throughout his career. Late works such as Portrait and a Dream (1953) set up this very opposition of the interior and the exterior, where the right hand side suggests a head, and the left-hand side suggests the dreams or fantasies erupting within. Potts goes on to discuss Roberto Matta, whose biomorphic landscapes were described by Öyvind Fahlström as 'not fairy-tales, but rather an "opened realism”, an inside-out realism' (p. 95). Here Pollock and Matta are brought into dialogue, rather than being considered as embodying opposing tendencies. Potts then moves on to Willem de Kooning, whose Women paintings are often regarded as a return to figuration. But Potts discusses a recurrent engagement by de Kooning with the world, where his gestural abstractions such as Merritt Parkway 
(1959) referred to the sensation of driving down the new freeway: works such as Gotham News (1955) prefigured Robert Rauschenberg's Combines with its use of collaged elements.

The next chapter turns to Europe, specifically the works of Wols and Jean Dubuffet. While their works offer convergences with their American counterparts, Potts notes that both were more explicit in making concrete reference to social and political issues. Wols was a photographer before turning to abstraction, while Dubuffet's Art Brut engaged with vernacular forms of representation and verbal signage. Both artists were also prolific writers, which makes an interesting connection with the remark above by Guston, who described his late painting as like writing. In each case, painting is subtended by language.

The second section, 'New Realism,' deals initially with the Independent Group, particularly Rayner Banham, Richard Hamilton and Eduardo Paolozzi. Here realism, for Potts, signifies an open-ness and embrace of heterogeneity, 'letting the world in,' to use Rauschenberg’s phrase. Banham's essay 'The New Brutalism’ (1955) provides a point of continuity with Art Brut (Dubuffet was cited, and his work illustrated in Banham's essay). Banham's views embraced a bloody-minded 'raw' aesthetic in art and architecture, made visible in the pavilions in This Is Tomorrow (1956), and in Paolozzi's sculptures of the 1950s. Banham's suggestive notion of the 'As Found' intimates the use of found imagery which populates Richard Hamilton's astute paintings such as \$he (1958-61) and Interior II (1964). The 'As Found' also relates to Paolozzi's complex screenprints from the 1960s. Suites such as As Is When (1965), although hailed as masterpieces of the medium, were an affront to traditional printmakers because of Paolozzi's use of ready-made photographic imagery culled from magazines and mail-order catalogues. However, by this stage the art under 
discussion is starting to put pressure upon Potts' definition of realism. Pop's realism has always been a matter of dispute amongst commentators, as to whether it constitutes a genuine engagement with the modern world, or a mere fascination with its surfaces. This is especially the case with American Pop, which Potts turns to in the next chapter. Before turning to the U.S., Potts first discusses the New Realism of Arman and Yves Klein. Their work is framed within the context of artists' dissatisfaction with existing vocabularies of art, following Pierre Restany's call for 'the direct appropriation of the real' (p. 204). Restany's claim was far from disinterested: it formed part of his promotion of the movement, and indeed this kind of showmanship played a large part in the work of Yves Klein, indicative of the increasing professionalisation of the artist during this period. It also revealed the increasing reliance of art upon institutional legitimation and systems of distribution. Nonetheless, Potts is sympathetic to both as offering a critique of consumption. The word 'consumer' has an anodyne cast in commonplace usage, but as Raymond Williams noted, the word has devouring connotations: it is a 'metaphor drawn from the stomach or the furnace.' ${ }^{9}$ Arman's emphasis upon the destructive nature of accumulation and consumption was acted out in his destruction of musical instruments (pianos in particular bearing the brunt of his destruction).

Unlike the social and political valence of much of the New Realist work, the screenprints of Warhol and the photo-paintings of Gerhard Richter are more detached. The discussion of their non-committal ambiguity is mostly familiar, although Potts' provides an interesting juxtaposition with Warhol's 'Disaster' series: Paolozzi's collage Laocoön, Seen Through the Windscreen of a Car (1961), which visualises the father and sons being ploughed down by an automobile. 
Section three, 'Assemblage,' examines Robert Rauschenberg and Cy Twombly. This connects to the earlier section on de Kooning: Rauschenberg's Combines took further the incipient elements of the real found in de Kooning's paintings by including real objects with the gestural brushmarks, creating composite image/objects which speak to our scrambled world of information overload. Twombly's evocations of classical literature and history, and his inclusion of verbal elements in works such as The Italians (1961), evoke a more explicit figurative reference (and in doing so, might open up an interesting comparison with Guston's own paintings during his time in Italy). The chapter concludes with Claes Oldenburg's 'soft' sculptures and installations at The Store, in conjunction with Ed Kienholz's squalid installation Roxy's (1962). Kienholz's The Beanery (1965) appears in the introduction, and it seems to be a provocation on Potts' part. The installation is paired with André Fougeron's Atlantic Civilisation (1953): a clumsy social-realist critique of American capitalism which makes a good case for modernist purity.

Kienholz is dismissed by Yve-Alain Bois in Art Since 1900, his work ridiculed for its 'maniacal redundancy.... his one-liners pounded into the beholder's head with a skull-crushing baseball bat. ${ }^{10}$ Kienholz offends Bois (and, presumably his coeditors) for being too much, too literal: the very reasons, in fact, that Guston's Marlborough paintings were attacked by Perrault, Hilton Kramer and Robert Hughes (incidentally, Guston's late work does not appear in Art Since 1900). Kienholz's work runs a perennial risk for any realist: that of showing, or revealing to the viewer more than is considered seemly. This ostentation eliminates the ambiguity beloved of the formalist (this is perhaps why waxworks look so odd and unsatisfactory from an aesthetic perspective). 
Potts then introduces two figures who are likely to be less familiar to the reader: Hérvé Télémaque, whose Pop paintings explored issues around colonialism and violence through crisp, brightly-coloured montage paintings; and Öyvind Fahlström, whose installation Dr. Schweizer's Last Mission (1964-6) graces the cover of the book. The installation appeared in the 1966 Venice Biennale: a dispersed collage of vinyl-coated magnetic metal panels, the work is an opened-out comic strip where the viewer was encouraged to participate in the work by moving the panels around (this is no longer permitted by the Moderna Museet in Stockholm where the work is held). Like Télémaque, Fahlström adopts a 'clean' aesthetic of crisp lines and surfaces, but the dispersed nature of the installation causes Potts to wonder 'what broader scenario, if any, is being conjured up as one scans the disparate but in some way also possibly interconnected tableau fragments...' (p. 303). Potts returns to these thoughts at the close of the chapter, where he claims that a 'For a work of art to be compellingly realist... it has to open itself up to contingencies of meaning and reference....' He adds that 'the articulation of a political message makes its strongest impression as one real element embedded in a larger, partly intractable world, rather than as an encompassing view of this reality...' (p. 318). Here Potts is shifting towards a more Brechtian commitment to a realism that acknowledges fragmentation and contingency. However, it is clear that the developments in the 1960s problematise what we understand to be 'real.'

This problem is also evident in Section Four, entitled 'Happenings, Actions, Hybrid Practices.' The first chapter turns back to Oldenburg-the Oldenburg of performances such as Snapshots from the City (1960) and The Street (1960)-rather than the soft sculptures discussed earlier. Potts notes that Oldenburg saw his work as a continuation of Abstract Expressionism rather than a rejection of it, paralleling the 
claim for Guston's late work as a belated form of action painting. Potts then provides a detailed and sympathetic account of Allan Kaprow's Happenings, drawing upon archival material to explain that Happenings were carefully considered and elaborately structured, despite their seemingly chaotic nature. Kaprow's work is not anti-art, but art which refreshes itself through its engagement with the real. It was an art which followed the tradition outlined in Leo Steinberg's 'Other Criteria' (1968) as being distinctively American in its suspicion of 'artiness,' looking to the broader parameters of experience. ${ }^{11}$

As it turned out however, Happenings, like most avant-garde movements, were relatively short-lived. They did not manage to enrich the realm of experience to the extent that Kaprow and others had hoped for. Joseph Beuys made a similar claim: that one day art would expand to the point where it would occupy the routines of everyday life, no longer recognised as art. ${ }^{12}$ Potts is sympathetic to Beuys. He ascribes the misconception of the artist- which undergirds critiques such as those of Benjamin Buchloh- to the catalogue of the artist's 1979 retrospective at the Guggenheim. This has led to the view of Beuys as a 'naïve shaman, a reactionary manipulator of atavistic symbols and an advocate of a romantic and politically compromised anarchism' (p. 366). Potts, however, regards Beuys' invocation of ritual as more self-conscious and performative. If Beuys has been misconstrued, this suggests something telling about the problem of realism in the 1960s and 1970s. In Christopher Lasch's The Culture of Narcissism (1979), he argued that as the culture of spectacle and the mass media rendered public life as an illusion, the avant-garde in art (particularly events such as Happenings) was attempting to bring the real into art, blurring those two modes. The consequence, according to Lasch, was neither a heightening of our sense of reality, nor the ability to see through illusion. Instead, 
there was widespread indifference and a cynicism which sees through illusion, and yet regards reality as unreal, lacking 'credibility. ${ }^{13}$ For Lasch, it is our very willingness to suspend belief that grounds our sense of reality. Much of Lasch's discussion is apposite with regard to the 'figured world.'

This weariness surfaces at the close of Potts' study, which concludes with the work of Asger Jorn. Potts describes Jorn's painting as operating though 'irony and negation' (p. 398). A less sympathetic observer might regard Jorn's pastiches of gestural abstraction, or his modifications of kitsch (which he called peintures détournés), as evidence of the breezy cynicism of certain variants of postmodernism. In this respect, Jorn counters Guston. Although Guston wrestled with the problem of expression-and the possibility that it may no longer be viable- there is no question that Guston believed in the potency of the creative act; in the notion of authenticity; and in the universality of Piero and Rembrandt: views which would be regarded as corny or naive by today's hip, Biennale-hopping contemporary artists. However, the strength of his late work seems to derive from this tension: from what Slifkin calls 'literal liberalism.' Guston really 'meant it,' and this earnestness prevents his paintings from descending into mere provocation, or the complacently 'bad' painting which has proliferated in his wake. One wonders how Guston might have figured in Potts' account as an example of critically-engaged realism. This is not intended as a criticism, but rather, as an indication of the way that these two studies illuminate each other, reinvigorating long-standing arguments about the nature of the real, and of art's relationship to it. 
${ }^{1}$ Daniel J. Boorstin, The Image: A Guide to Pseudo-events in America [1962] (New York: Vintage, 1992).

2 Jay Parini, 'A Life in Feuds: How Gore Vidal gripped a nation,' Guardian, 14 August 2015. Excerpt from Every Time a Friend Succeeds Something Inside Me Dies:

The Life of Gore Vidal (London: Little, Brown, 2015).

${ }^{3}$ Rosalind Krauss, 'Stella's New Work and the Problem of Series,' Artforum, (December 1971), 40-44.

${ }^{4}$ Guston recounts this in 'Talk at "Art/Not Art” Conference,' University of Minnesota, Minneapolis, February 27, 1978. Republished in Philip Guston: Collected Writings, Lectures and Conversations, ed. Clark Coolidge (Berkeley: University of California Press, 2011), 282.

${ }^{5}$ For more on this, see Robert Slifkin, 'The Tragic Image: Action Painting Refigured,' Oxford Art Journal 34:2 (2011), 227-246. See also Christa Noel Robbins, 'Harold Rosenberg on the Character of Action,' Oxford Art Journal, 35:2 (2012), 195-214.

${ }^{6}$ Philip Guston: Collected Writings, Lectures and Conversations, 252.

${ }^{7}$ See Michael Fried, 'Three American Painters,' in Michael Fried, Art and Objecthood: Essays and reviews (Chicago and London: University of Chicago Press, 1996); and Michael Fried, 'How Modernism Works: A response to T.J. Clark,' in Pollock and After: The critical debate, ed. Francis Frascina (New York: Harper and Row, 1985).

${ }^{8}$ Charles Harrison, Since 1950: Art and its Criticism (New Haven and London: Yale University Pres, 2009), 87.

${ }^{9}$ Raymond Williams, 'Advertising: The Magic System,' in Culture and Materialism: Selected Essays (London and New York: Verso, 2005), 209. 
${ }^{10}$ Yve-Alain Bois, '1959b,' in Hal Foster et al, Art Since 1900 (London: Thames and Hudson, 2004), 418-20.

${ }^{11}$ Likewise, Guston, in a public discussion at Yale in 1972, quoted Grandma Moses:

'Forget about art, we're busy...' In Philip Guston: Collected Writings, Lectures and Conversations, 155.

${ }^{12}$ As Charles Harrison wryly remarked: 'Perhaps the time has come. Perhaps not. How would we know?' in Charles Harrison, Conceptual Art and Painting: Further essays on Art \& Language (Cambridge, MA and London: MIT Press, 2001), 38.

${ }^{13}$ Christopher Lasch, The Culture of Narcissism (New York: WW Norton, 1979), 8687. 